\title{
The Ethics of Employment-at-Will: An Institutional Complementarities Approach
}

\author{
Vikram R. Bhargava \\ George Washington University
}

Carson Young

SUNY Brockport

\begin{abstract}
Employment-at-will (EAW) is the legal presumption that employers and employees may terminate an employment relationship for any or no reason. Defenders of EAW have argued that it promotes autonomy and efficiency. Critics have argued that it allows for the domination, subordination, and arbitrary treatment of employees. We intervene in this debate by arguing that the case for EAW is contextual in a way that existing business ethics scholarship has not considered. In particular, we argue that the justifiability of EAW for a given jurisdiction depends on existing complementarities among the institutions that constitute the jurisdiction's political economy. Notably, our view takes seriously the ethical concerns EAW critics have raised by showing how these concerns can be mitigated through public policy measures that do not require eliminating EAW.
\end{abstract}

Key Words: employment-at-will, employee rights, contract at will, just-cause dismissal, employment ethics, employment law

$\mathrm{E}$ mployment-at-will (EAW) is a legal default rule that holds that both employers and employees may, with or without warning, terminate an employment relationship for any or no reason. EAW is the legal presumption in the majority of employment relationships in the United States. In contrast to jurisdictions that adopt for-cause employment rules that legally mandate justification before a party may terminate the employment relationship, in jurisdictions with EAW, the employment relationship is largely unprotected. EAW has generated vigorous debate in the last three decades.

Critics of EAW have argued that it permits employees to be exploited, dominated, and treated in arbitrary and unfair ways that are at odds with respecting the dignity of persons (Anderson, 2015, 2017; McCall, 2003; McCall \& Werhane, 2009; Radin \& Werhane, 1996, 2003; Werhane, 1999; Werhane \& Radin, 1999; Werhane, Radin, \& Bowie, 2004). Moreover, the nearly untethered latitude EAW grants employers in firing decisions can result in the chilling of employee speech-even when the employees are off-duty - a result that undermines the realization of important political values (Barry, 2007a, 2007b).

But EAW is not without defenders. Supporters of EAW have argued that it protects and enhances the autonomy of both employers and employees (Epstein, 
1984; Maitland, 1989). They point out that EAW is symmetrical—both employers and employees benefit from the freedom to exit the employment relationship-and that the prevalence of EAW suggests that it is the preferred sort of employment relationship for both employers and employees (Maitland, 1989). Other arguments suggest that EAW is worth adopting or preserving because it promotes efficiency in labor markets (Epstein, 1984).

Both the critics and defenders of EAW have marshaled a range of powerful arguments to support their positions. But the debate now seems to be at a standstill. Our first task in this article is to diagnose the state of the debate in the existing literature on the ethics of EAW. We argue that much of the debate surrounding EAW has involved one side talking past the other: the main position that EAW critics defend is not a position that EAW defenders deny.

Our diagnosis motivates the article's second task, which is to advance the EAW debate by building a normative business ethics theory about the justifiability of EAW. We argue that blanket prescriptions for or against EAW are unjustified. Instead, we develop what we call an institutional complementarities approach to EAW. According to this approach, the justifiability of EAW in a given jurisdiction depends on the configuration of that jurisdiction's economic institutions. Some jurisdictions have adopted interdependent configurations of economic institutions that magnify the value of having flexible labor markets. Such jurisdictions have reason to adopt or maintain EAW. Other jurisdictions have adopted interdependent configurations of economic institutions that magnify the value of developing longterm employment relationships that facilitate the development of employees' firmand industry-specific skills. Such jurisdictions have reason to adopt or maintain forcause dismissal rules for employment. Thus we hold that the case for EAW is highly dependent on institutional context.

Our broader institutional economics perspective also yields insights about how to address the ethical concerns of EAW's critics. We take these concerns seriously. However, we claim that they do not necessarily justify eliminating EAW in the way critics hold. Instead, we suggest some alternative public policy measures that mitigate EAW critics' concerns while preserving EAW. ${ }^{1}$

We proceed as follows. In section 1, we claim that many of the criticisms of EAW involve characterizing certain wrongful ways of treating employees that are legally permissible under EAW. These criticisms miss their mark for two reasons. First, showing that EAW permits unethical conduct is insufficient for demonstrating that EAW should be replaced with a for-cause employment rule. Second, defenders of EAW are not advancing claims about whether certain ways of treating employees are

\footnotetext{
${ }^{1}$ Although issues related to EAW are particularly salient in the US context (and in other countries that have employment law similar to EAW), our discussion is also significant for managers and scholars outside the US context. Managers operating within multinational businesses in our contemporary global economy cannot avoid attending to the nature of employment within the United States. For example, international firms that have offices in the United States cannot skirt developing a more sophisticated understanding of issues related to employment law and EAW. With respect to the theoretical upshot, our positive justification of EAW also sheds light on the contours and limits of the just cause employment regimes that are currently dominant in much of the world.
} 
wrongful - they are defending claims about what the law should be. Hence, as we show, the main views EAW's critics advance are compatible with the views of EAW's defenders. As a result, EAW's critics have mostly been talking past its defenders.

In section 2, we consider a different kind of argument against EAW — what we call a direct argument - that holds that it is morally impermissible to have a legal regime that even in principle permits wrongful treatment of employees. These direct arguments do not involve talking past EAW's defenders. Here we focus largely on Elizabeth Anderson's $(2015,2017)$ recent work. We conclude that the direct arguments do present a significant moral challenge to EAW.

In section 3, we introduce Hirschman's (1970) distinction between voice and exit as institutional strategies for protecting workers from abuse. We argue that, in the right circumstances, ensuring workers' right to exit can protect workers from injustice. This suggests a qualified defense of EAW that takes seriously the concerns raised by EAW's critics, while offering a different approach to institutional design than the one that EAW critics typically favor. We propose five categories of policy measures that complement EAW, together helping to secure employees' right to exit. As a result, depending on context, we argue that both EAW and non-EAW rules are, or at least can be, consistent with requirements of justice.

In section 4, we present our institutional complementarities argument for EAW. To do so, we highlight some considerations that are largely absent from previous debates about EAW in the business ethics literature: the nature of the society's economic institutions and how these interact with that society's employment law. In particular, we argue that societies with flexible labor market institutions have strong reason to adopt (or maintain) EAW, whereas societies that rely more on employees investing in firm- or industry-specific skills have strong reason to adopt (or maintain) for-cause dismissal.

In section 5, we discuss the implications of our view for the ethics of hiring and firing. ${ }^{2}$ As critics of EAW, such as Anderson (2015, 2017), Werhane et al. (2004), and McCall (2003), have argued, EAW allows employers to treat employees in ethically unacceptable ways. In this section, we discuss some of the ethical requirements by which employers (and employees) in EAW regimes are constrained and

\footnotetext{
${ }^{2}$ In a number of jurisdictions in the United States, there are three broad classes of exceptions to the presumption of EAW: public policy exceptions, contractual exceptions, and covenant-of-good-faith exceptions (Muhl, 2001). The public policy exception precludes firings that undermine a state's public policy interests (e.g., firing an employee for fulfilling his or her jury duty obligations or for failing to perpetrate a crime). A contractual exception requires the presence of a valid contract that stipulates constraints on firing (e.g., the contracts of tenured university professors or the presence of collective bargaining agreements). In some cases, there can be implied contractual exceptions when the employer creates certain assurances (even if these assurances are not expressed in a contract), for example, if the company's employee handbook states that the employee cannot be fired absent just cause. The covenant-of-good-faith exception precludes certain bad-faith or malicious terminations, for example, firing the employee just prior to having to disburse the employee's retirement benefits. In addition to these three classes of exceptions, there are statutory exceptions to EAW that would prohibit firings that violate state or federal statutory requirements (e.g., firings that discriminate against the constitutionally protected classes, such as race, gender, and sexual orientation) (Bennett, Polden, \& Ruben, 1998).
} 
conclude that the ethical requirements in the employment realm are plausibly more stringent in EAW regimes than in for-cause regimes.

Finally, in section 6, we conclude by discussing the implications of our work for future research. We show how some of the main conclusions of our arguments point the way to some general features that any comprehensive account of employment ethics should satisfy. In other words, although we do not provide a comprehensive theory of employment ethics in this article, we show how our discussion illuminates several desiderata for a comprehensive theory of employment ethics.

\section{DIAGNOSING THE STATE OF THE EAW DEBATE}

The EAW debate encompasses at least four distinct types of questions:

1) Should it be legally permissible for an employer to fire an employee for a bad reason or no reason, and without warning?

2) Should it be legally permissible for an employee to quit for a bad reason or no reason, and without warning?

3) Would it be wrong for a business to fire an employee for a bad reason or no reason, and without warning?

4) Would it be wrong for an employee to quit for a bad reason or no reason, and without warning?

Defenders of EAW answer 1) and 2) affirmatively but do not speak to 3) or 4) (Epstein, 1984; Maitland, 1989). Business ethicists criticizing EAW, on the other hand, answer 3) affirmatively (McCall \& Werhane, 2009; Werhane \& Radin, 1999), and some seem even to affirm 4) (Werhane et al., 2004). ${ }^{3}$ As a result, we will argue, critics of EAW are talking past its defenders.

In other words, what initially appears to be a debate over a single issue-EAWupon closer examination turns out sometimes to involve defending a set of claims about how employers and employees should act, on one side of the debate, and a set of claims about what the law should be, on the other. The main positions the two sides defend are mutually compatible. Thus we ought not understand them to be occupying two "sides" of a debate in the conventional sense.

Consider the position of the defenders of EAW. The arguments in favor of EAW justify a claim about what governments can (or cannot) justifiably mandate. This is seen from the fact that defenders of EAW contrast their subject of concern from nonlegal approaches. For instance, in his seminal defense of EAW, Richard Epstein (1984: 952) writes, "The critics of the contract at will all point out imperfections in the current institutional arrangements, but they do not take into account the nonlegal means of preserving long-term employment relationships." Even more tellingly, influential statements of the legal doctrine of EAW build dismissal for morally

\footnotetext{
${ }^{3}$ Where critics of EAW stand with respect to 2) is a question that, to our knowledge, has not been addressed in the literature.
} 
wrong reasons into their conception of EAW: "All may dismiss their employees at will, be they many or few, for good cause, for no cause or even for cause morally wrong, without being thereby guilty of legal wrong" (emphasis added). ${ }^{4}$ It is clear where defenders of EAW stand: they defend the legal permissibility of employers or employees to terminate the employment relationship for any or no reason and with or without warning. Thus EAW's defenders should not be read as endorsing the unethical behavior that EAW regimes judge legally permissible.

But what about the critics? At least some seem to present arguments for the various ways in which it would be wrong to treat employees under EAW. In Patricia Werhane et al.'s view, EAW allows employers to treat employees in arbitrary ways, and this is at odds with how persons should be treated - that is, with respect:

EAW, however, permits arbitrary layoffs, and this leeway is problematic. When I get rid of a robot, I do not have to give reasons, because a robot is not a rational being. It has no emotions and no use for reasons. On the other hand, people do reason and feel, and they feel an entire range of emotions. If I fire a person arbitrarily, I am making the assumption that he or she does not need reasons. But if I have hired people, then, in firing them, I should treat them as such, with respect, throughout the termination process (Werhane et al., 2004: 70).

This is an influential position in the debate. It is a position about a wrongful way of treating one's employees. McCall (2003: 167) makes a similar point: "Terminating a person's employment for no reason or for purely personal reasons is the epitome of arbitrary treatment." The position that these EAW critics defend-that it is wrong to treat employees in arbitrary ways-is a view about how employers should treat their employees.

But few, if any, defenders of EAW suggest that managers should terminate an employee for no reason, arbitrary reasons, or purely personal reasons. Defenders of EAW are concerned with what ought to be legally permitted. However, the view that it ought to be legally permissible for an employer to terminate an employee arbitrarily is entirely consistent with the view that it is ethically impermissible for an employer to terminate an employee arbitrarily. This is the sense in which defenders and critics of EAW have been talking past each other.

One could object that critics of EAW are using the very arguments they develop in defense of an affirmative answer to 3) (it is wrong to fire an employee for a bad reason or no reason, and without warning) also to justify a negative answer to 1) (it should not be legally permissible to fire an employee for a bad reason or no reason, and without warning) — call this the indirect argument against EAW. If this argument is cogent, then EAW's critics would not be talking past its defenders.

But the indirect argument against EAW omits crucial premises and is thus invalid. Showing that something is wrongful is uncontroversially insufficient grounds to justify legal prohibition of that thing. For example, generally, it is unethical to lie, but it does not follow that lying in general ought to be legally prohibited.

\footnotetext{
${ }^{4}$ See Payne v. Western \& Atlantic Railroad Co., 81 Tenn. 507 (1884): 520.
} 
Moreover, the criticisms of EAW that focus on wrongful ways of treating employees are not adequately tailored to the employment context. That is to say, the EAW critics' arguments we have considered thus far can be put in such a way that they would make no reference to the employment relation: not treating people arbitrarily or unfairly is part and parcel of what morality demands, not just of managers, but of people more generally. Indeed, many relationships, for example, friendships, mentorships, and romances, as well as relationships with customers, suppliers, and marketing agencies, legally allow for immoral treatment of one or both of the parties that constitute the relationship - they are, in a sense, at-will.

One might be tempted to understand our point here as one about law versus ethics. But this is not quite right. Our point is that the defenders and the critics of EAW are responding to different ethical questions. EAW's defenders have focused on the question of what the law should be, ${ }^{5}$ whereas EAW's critics have focused on the question of how employees should be treated. These are both ethical questions, but distinct ones: a cogent answer to the latter question is not alone adequate for an answer to the former. Therefore a successful critique of EAW must have a different kind of structure, one that involves an argument against the very principle of EAW, quite apart from particular abuses of it.

Focusing on the wrongful ways of treating employees thus results in talking past EAW's defenders. Merely showing that EAW legally permits conduct that is unethical does not alone give us reason to reform EAW in the way EAW critics have insisted we must. For this reason, we reject Werhane et al.'s (2004: 73) claim that "the most telling argument against at-will employment does not... question the principle itself but rather raises issue about its abuses."

\section{DIRECT ARGUMENTS AGAINST EAW}

To build a successful case against EAW, critics must provide an argument that establishes the wrongness of minimal legal regulation in the employment context. Such an argument would be for the view that the sorts of unethical conduct of employers toward their employees that are legally permitted under EAW ought to be legally prohibitedcall this a direct argument against EAW. If EAW critics were able to provide a direct argument against EAW, then they would no longer be talking past EAW defenders.

Let's now consider some direct arguments against EAW. Perhaps Werhane et al.'s (2004) arguments can be modified to hold that it is wrong to have a legal regime that allows employers to treat employees in an arbitrary manner. Another potential direct argument is provided by McCall (2003). He argues, "Given the unavoidable and central role that employment plays in contemporary life, a policy that allows employers to demand ever-increasing productivity under threat of dismissal is an unreasonable policy" (168). Each of these arguments attacks the legal regime of EAW itself as being morally unjustifiable.

\footnotetext{
${ }^{5}$ Notice that with this question, though the subject matter is the law, the question itself is one of ethics. This is evidenced by the fact that some of the most prominent answers to the question involve appealing to ethical considerations (autonomy, liberty, etc.) (Epstein, 1984; Maitland, 1989).
} 
Although these two arguments have the correct sort of structure, we believe the most promising direct argument against EAW does not come from these arguments. This is for two reasons. First, while we regard direct arguments against EAW to be a promising way to criticize EAW, as mentioned earlier, Werhane et al. (2004: 73) do not seem to think so and thus might not endorse our reconstruction of their view into a direct argument against EAW. Second, although McCall's is the right kind of argument, at least as stated, it moves too fast. This becomes clear once we distinguish between the ability to terminate employment from a constant threat of termination.

Consider an example in a different context: if I am in a romantic relationship, I have the ability to break up, but this ability does not mean that I am threatening to break up. Though employment relations and romantic relations are normatively distinct kinds of relations, the point is merely that the fact that an employer can terminate the relationship does not entail that the employer is threatening to terminate it. (Relatedly, it would be odd to think that an employee in an EAW regime is threatening to quit merely because the employee has the ability to terminate the employment relationship.) Possessing the ability to terminate the employment relationship does not, on its own, mean that those in the relationship are "under threat of dismissal." For these reasons, despite these two direct arguments possessing the correct structural features, we believe that the most promising direct argument against EAW comes from elsewhere: Elizabeth Anderson's $(2015,2017)$ recent work. However, it is worth noting that the upshot of our ensuing analysis straightforwardly bears on direct argument variants of Werhane et al.'s (2004) view and the direct argument put forth by McCall (2003).

Anderson claims that modern corporations, especially in the United States, increasingly resemble oppressive, dictatorial governments. Many employees are subject to orders and sanctions of their employers without having any significant voice in how they are ordered and sanctioned. The power employers exercise over their employees is often arbitrary and unaccountable. It is thus a grave threat to employees' republican freedom, which individuals enjoy if and only if they are free from domination by the arbitrary and unaccountable will of others (Anderson, 2015, 2017; Pettit, 1997).

According to Anderson $(2015,2017)$, EAW is an important element of an overall set of political and economic institutions that facilitates employers' domination of employees. When employers can fire employees for any or no reason, they in a key sense have authority over their employees not only during work hours but also during times when employees are off-duty (see Barry, 2007a, 2007b; Bhargava, 2020). EAW thus contributes not just to domination during work hours but to a more encompassing domination that pervades both the work lives and private lives of many employees.

One tempting response to Anderson in defense of EAW is to point out the symmetry of rights and liberties that EAW grants both employers and employees. Although EAW allows employers to terminate the employment relationship for any or no reason, it also allows employees to do the same. By giving employers and employees equal rights to exit the employment relationship, EAW helps ensure that 
neither employees nor employers possess disproportionate authority over those with whom they share an employment relationship (Alchian \& Demsetz, 1972).

Anderson $(2015,2017)$, however, rejects the suggestion that this apparent symmetry between the two sides of the employment relationship can vindicate EAW. In many cases, employers have vastly more negotiating power than employees (Bowles \& Gintis, 1992). Quitting is often a much less viable or attractive option for employees than dismissing a worker is for employers: quitting often imposes significant costs on employees because it prevents them from qualifying for employment insurance to which they would have a right if they were fired (Anderson, 2015: 107). Thus employees typically have little or no effective power to negotiate the terms of their employment, with the exception of those who have rare, sought-after skills or are members of a union. ${ }^{6}$

One important lesson from Anderson's $(2015,2017)$ work is that the power that employers enjoy over employees under the contemporary American regime of employment law should not be understood as the product of neutral political or market processes whose emergent patterns result from many individuals exercising free choice. As Anderson argues, the power asymmetry between employers and employees comes from the background economic, political, and legal institutions that provide the context in which individual members of society exercise their choices. In other words, "it is the state that establishes the default constitution of workplace governance. It is a form of authoritarian, private government, in which, under employment at-will, workers cede all their rights to their employers, except those specifically reserved for them by law" (Anderson, 2015: 110).

We grant here that the concerns raised by Anderson are legitimate: a society with the domination and subordination of workers does seem to be a troubling one. Similarly, we also grant that the points raised by the direct argument variants of EAW's earlier critics (McCall, 2003; Werhane et al., 2004) reflect serious ethical concerns. In other words, we grant that the direct arguments succeed in presenting a serious challenge for defenders of EAW. However, while we accept EAW critics' ethical concerns, we differ with them on questions of institutional design. The next two sections explain why.

\section{IS ELIMINATING EAW A REQUIREMENT OF JUSTICE?}

\subsection{Voice and Exit: Two Strategies for Protecting Workers from Domination and Arbitrary Treatment}

Anderson (2015: 111) emphasizes that freedom "of entry and exit from any employment relation is not sufficient to justify the outcome." We agree that the mere fact that parties enter an employment arrangement voluntarily does not guarantee that the

\footnotetext{
${ }^{6}$ We acknowledge that arriving at sound assessments of an employee's bargaining power can be a complicated matter. For example, even for employees who do not have rare skills or are not part of unions, broader macroeconomic conditions, labor market conditions, or microeconomic factors affecting supply and demand have important consequences for an employee's bargaining power. We thank the former editor of this journal for raising this point.
} 
arrangement is justified. But one can, without inconsistency, recognize that the right to exit is insufficient to guarantee the justice of an employment arrangement, while still insisting that supporting workers' right to exit is an important mechanism for protecting workers from domination and arbitrary treatment. One way to understand the importance of the right to exit is to consider the plight of people who lack it. Employees who lack a viable right to exit face a situation that is analogous in certain important respects to that of sweatshop workers: a main reason why ethicists consider sweatshop workers to be vulnerable to exploitation is that the workers lack decent alternatives to working in a particular sweatshop (Arnold, 2009; Goodin, 1986; Snyder, 2010; Zwolinski, 2007).

It is helpful to distinguish exit and voice as strategies for protecting workers from domination and arbitrary treatment (Hirschman, 1970). Giving workers voice, for example, by adopting democratic workplace reforms, empowers workers to protect themselves by expressing dissent or by participating in democratic decision-making procedures, such as majority votes (Hsieh, 2005). Supporting workers' right to exit, for example, by adopting policies that promote employer competition for employees and ensuring that workers have the resources required for exit to be a viable option for them, empowers workers to protect themselves by leaving employment relationships that they feel are unsatisfactory.

Theorists who are animated by a concern for preventing domination in social relationships disagree about the extent to which we should prioritize voice strategies versus exit strategies when making policies that govern labor market relations (Anderson, 2015; Estlund, 2018; Taylor, 2017). Our view is that the arguments these theorists offer underdetermine whether policy makers should ultimately favor voice strategies over exit strategies, or vice versa. There is good reason to believe that, depending on circumstances, both strategies that rely heavily on voice and strategies that rely heavily on exit can adequately protect workers from domination. Some jurisdictions, whose regulatory environments feature certain complementary policies, ought to rely heavily on exit strategies rather than voice strategies; but other jurisdictions, with regulatory environments that feature other kinds of complementary policies, rightly rely more heavily on voice strategies than on exit strategies.

Understanding the justification for our view requires understanding how voice and exit strategies can both substitute for and complement each other, depending on the circumstance. As Taylor (2017) argues, under the right institutional conditions, the right to exit can serve as an effective substitute for voice as a means for employees to ensure that employment arrangements track their interests. When labor markets are competitive and employer demand for labor is high, employers must compete for workers by ensuring that the employment conditions they offer track workers' preferences, as revealed through their voice and exit decisions, more closely than the employment conditions offered by their competitors. Moreover, when exit is a live option for employees, and when labor market participants know that exit is a live option for employees, the right to exit often will not even need to be exercised. Under these conditions, exit can serve as a complement to voice, not just as a substitute: "potential exit can empower voice, forcing providers to heed the words of their clients, be they words of instruction, explanation, or complaint" (Taylor, 2017: 3). 
However, although voice and exit can complement each other under the right conditions, advocates of voice over exit are quick to point out that exit can sometimes undermine voice and increase vulnerability to domination on net, especially for the most vulnerable. Exit can allow privileged community members to abandon less-privileged community members for whom exit is not a real option, sapping the power of more vulnerable members' voices. A famous example of this comes from Hirschman (1970), who argues that allowing privileged families to abandon public school systems and send their children to private schools leaves public schools without the (typically amplified) voices of more privileged parents. As a result, the overall power and efficacy of those who advocate on behalf of public school children is reduced, to the disadvantage of the less-privileged children who remain in the public school system.

The upshot of these interactions between voice and exit strategies, argues Taylor (2017), is that, for the security of disadvantaged people from domination and arbitrary treatment, the relationship between voice strategies and exit strategies is likely to be nonmonotonic: "it first falls with the ease of exit, as the most advantaged leave and no longer raise their voices against abuse, but then rises again as even the less advantaged are able to depart or credibly threaten to do so" (6). In other words, we have reason to believe that institutional design strategies that make exit feasible for many privileged members, but infeasible for many less-privileged members, are suboptimal in terms of securing people from domination and arbitrary treatment compared to institutional design strategies that either make exit feasible for most members or make exit infeasible for most members but compensate for this by adopting other policies that amplify members' voices (e.g., in the employment context, works councils and corporate board seats for employee representatives).

It is important to understand EAW, and the alternative policy of a for-cause dismissal rule, not in isolation but as one part of a broader political, economic, and legal institutional environment whose ultimate purpose must be promoting justice and preventing injustice (which we take to include preventing domination and arbitrary treatment). Viewed from this perspective, Taylor's argument suggests that EAW may facilitate domination and arbitrary treatment in institutional contexts that make exit a feasible option only for a small proportion of workers (by allowing only more privileged workers to escape) but that it may also help to secure workers from domination and arbitrary treatment as part of a broader array of policies that help ensure a viable right to exit for most or all workers (including the least privileged).

\subsection{How an EAW Jurisdiction Can Be Just}

As McCall's (2003) direct argument and the direct argument variant of Werhane et al.'s (2004) view show, EAW gives employers much greater latitude than forcause employment regimes to dismiss employees, including for reasons that are arbitrary or unfair. ${ }^{7}$ Anderson's $(2015,2017)$ concerns are in some ways similar but

\footnotetext{
${ }^{7}$ Identifying whether there is a just cause for a termination in for-cause regimes is a thorny matter. According to Carroll Daugherty's (1966: 363-65) canonical statement of what constitutes a just cause, it involves the following seven tests: " 1 . Did the company give to the employee forewarning or foreknowledge
} 
also more focused on systemic problems with persistent unequal power relations: EAW must be eliminated because it subjects employees to domination by the arbitrary and unaccountable will of their employers. The ability to dismiss employees for any or no reason can give employers de facto control not only over employees' work activities and time spent on the job but also over their off-job activities, the opinions they express about nonwork topics (including political opinions) (Barry, 2007b, 2007a; Estlund, 1995, 2007), and other aspects of their private lives (Sugarman, 2003). ${ }^{8}$

Granting that these instances of domination and arbitrary treatment represent injustices, should we eliminate EAW to address them? We contend that the answer to this question is less straightforward than EAW critics assume. Even though the ability to dismiss employees at will gives employers power over their employees in certain respects, EAW also protects employees from abuse by helping secure their right to exit. It does this not only by protecting employees' legal right to leave their jobs but also by reducing firms' cost of hiring and firing. Lower hiring costs for firms contribute to more job turnover and reallocation (Skedinger, 2011). Thus determining whether EAW should be eliminated requires doing comparative institutional analysis that accounts for how EAW interacts with other aspects of a jurisdiction's regulatory environment, rather than just highlighting injustices that can be attributed to EAW.

EAW alone is, of course, insufficient to ensure a right to exit that effectively protects workers from domination. For exit to restrain arbitrary power effectively, it must be not only legally enabled but also economically feasible and costly to potentially abusive employers (Taylor, 2017: 4). Hence, to understand how a regime with EAW could secure employees against domination and arbitrary treatment enough to qualify as just, we need to understand which complementary policy measures could support the right to exit that EAW legally enables by ensuring that exit is feasible to workers and costly to abusive employers.

of the possible or probable disciplinary consequences of the employee's conduct?... 2. Was the company's rule or managerial order reasonably related to (a) the orderly, efficient, and safe operation of the company's business and (b) the performance that the company might properly expect of the employee?... 3. Did the company, before administering discipline to an employee, make an effort to discover whether the employee did in fact violate or disobey a rule or order of management?... 4. Was the company's investigation conducted fairly and objectively?... 5. At the investigation did the 'judge' obtain substantial evidence or proof that the employee was guilty as charged?... 6. Has the company applied its rules, orders, and penalties evenhandedly and without discrimination to all employees?... 7. Was the degree of discipline administered by the company in a particular case reasonably related to (a) the seriousness of the employee's proven offense and (b) the record of the employee in his service with the company?" For a more developed theoretical basis of the concept of a just cause in the employment realm, see Abrams and Nolan (1985). For a more recent account of just cause in employment that is responsive to the various court decisions in the decades following Daugherty's influential statement, see Koven and Smith (2006). More recent just cause tests that modify Daugherty's seven tests include the US Postal Service test and the Merit Systems Protection Board's "Douglas Factors" (for a detailed discussion, see Reeves, 2016).

${ }^{8}$ It is worth pointing out that employment protections in the United States cannot always be understood as a blanket at-will provision. For example, the protections, rights, and corresponding duties of employers and firms vary by whether it is public- or private-sector employment. Notably, in public-sector employment, issues related to freedom of speech manifest in different ways than in the private sector. For more on how this distinction between the private and public sectors bears out in employment law and ethics, see Barry (2007b). 
The following are five types of policies that can help fulfill these two desiderata: monetary policy, social welfare programs, social insurance programs, policies that reduce job lock, and reductions to barriers to entrepreneurship.

\subsubsection{Monetary Policy}

Karl Marx argued that the development of the capitalist economy created a reserve army of the unemployed that prevented labor from bargaining for higher wages (Marx, 2019). The low unemployment rates some capitalist economies have at times achieved since Marx's time suggest that he overstated his case (see, e.g., Kenworthy, 2002). Marx was correct, however, that high rates of unemployment reduce workers' bargaining power, especially in lower-skill occupations (Katz \& Krueger, 1999): when there are relatively many unemployed workers looking for jobs, it is more difficult for employees to secure better wages and more generous benefits because it is easier and cheaper for firms to recruit new employees than when unemployment is low. Additionally, the stakes of potential termination to employees are more significant when, due to high unemployment, employees are likely to struggle to find another job. Finally, and importantly, the cost that worker exit imposes on potentially abusive employers is greater when unemployment is low and labor markets are tight, because potential replacements for an employee who exercises her right to exit are scarce.

Many modern central banks, including the US Federal Reserve (US Fed), pursue a dual mandate to ensure full employment while also maintaining stable prices and a low, predictable rate of inflation. Some economists argue, however, that the US Fed has been systematically biased in favor of an excessively low level of inflation (Ozimek \& Ferlez, 2018), which contributes to higher unemployment. Thus monetary policy offers one avenue of policy reform for people who want to alleviate dominating, oppressive conditions in the workplace. Central banks could give greater priority to sustaining tight labor markets in which there are relatively few available unemployed workers relative to employer demand. Tight labor market monetary policy reform thus represents one promising avenue for policy reform to address workplace domination concerns.

\subsubsection{More Generous Social Welfare Programs}

A social welfare program aims to provide for people's basic needs and promote their well-being. Programs that provide health care for people below a certain income threshold and income-capped vouchers that allow people to purchase food or housing are examples of social welfare programs. Making these programs more generous would improve the capacity of people to weather unemployment by providing them with basic needs when they are unable to earn an income. A potentially more radical policy might involve some sort of universal basic income. On the margin, making social welfare programs more generous will, in addition to other potential benefits, modestly reduce the burdens of unemployment, making it easier for workers to escape situations in which they are vulnerable to domination. 


\subsubsection{More Robust Social Insurance Programs}

Whereas social welfare programs aim to provide for people's basic needs and promote their well-being, social insurance programs pool risks to reduce the variance in potential outcomes that each individual participant faces. Examples include unemployment insurance, health insurance, retirement insurance, and worker disability insurance. When social insurance programs are more robust, workers face greater protection from downside risks associated with losing their jobs. Thus another promising avenue of policy reform for those who want to make employees less vulnerable to domination or subordination is to make social insurance programs more robust.

\subsubsection{Reduce Job Lock}

Some countries have adopted policy regimes that contribute to a phenomenon called job lock, where social insurance programs and other benefits are tied to an employee's specific job (Madrian, 1994; Stroupe, Kinney, \& Kniesner, 2001). In the United States, which relies on an employer-sponsored scheme for health insurance, the job lock phenomenon is especially pronounced. A recent literature review of job lock in the United States reports that job lock reduces the rate at which people with employer-sponsored health insurance change jobs or leave their jobs to start their own businesses by 15-25 percent (Baker, 2015). In other words, job lock raises barriers employees face to leaving their current employment. This reduces their ability to leave situations in which they are vulnerable to domination or subordination on the part of their employers.

\subsubsection{Reduce Barriers to Entrepreneurship}

One way for an employee to escape a workplace in which the employee is vulnerable to domination or subordination is to start his or her own small business. This will not be a viable option for all or even most employees-many people lack the skills, abilities, motivations, or capital necessary to successfully launch their own businesses. However, reducing the procedures, time, and cost to start a small business, build new buildings, register property, and obtain electricity; ensuring a well-functioning credit system and adequate investor protections that expand entrepreneurs' access to capital; and reducing licensing requirements that raise the costs of starting certain kinds of business can help make the option of becoming an entrepreneur available to people who would potentially be well suited to running their own businesses. On the margin, this will expand the exit options of employees who wish to leave workplace situations that are prone to domination and subordination.

To conclude this section, it is plausible that justice requires eliminating the domination and subordination of workers. ${ }^{9}$ But even if we grant that EAW may,

\footnotetext{
${ }^{9}$ We acknowledge the possibility that defenders of EAW might not endorse a thicker conception of justice that requires lessening or eliminating the domination or insubordination of workers and might instead adopt a conception of justice that merely involves negative duties not to violate rights. Two points: first, it seems at least plausible that many defenders of EAW would admit that firing an employee for an arbitrary reason (e.g., because there is an odd number of letters in the employee's name) is in some way morally inappropriate, even
} 
in some cases, facilitate the domination and arbitrary treatment of workers, eliminating EAW will only qualify as a requirement of justice if there is no alternative set of policy changes that could eliminate the domination and arbitrary treatment of workers while leaving EAW in place. However, we have just identified five policy changes that have the potential to address the vulnerability of employees to domination and arbitrary treatment by their employers. ${ }^{10}$ If these (and perhaps other) policy changes could address the injustices that critics attribute to EAW, then eliminating EAW is not itself a requirement of justice. ${ }^{11}$ Thus, even though justice requires societies to eliminate workplace domination and arbitrary treatment, a given jurisdiction may permissibly retain EAW as long as it addresses workplace domination and arbitrary treatment through other means.

\section{AN INSTITUTIONAL COMPLEMENTARITIES ARGUMENT FOR EAW}

If we are correct that ending EAW is not a requirement of justice, then societies can permissibly maintain EAW, or implement it if they do not have it already. We now propose a potential justification for EAW that is distinct from those present in the existing EAW literature. This justification is rooted in insights from institutional economics.

Institutional economics has informed many subfields of business scholarship, including corporate social responsibility (e.g., Campbell, 2007; Ioannou \& Serafeim, 2012; Matten \& Moon, 2008), strategic management (e.g., Peng, Sun, Pinkham, \& Chen, 2009), international business (e.g., Jackson \& Deeg, 2008), and corporate governance (e.g., Aguilera, Filatotchev, Gospel, \& Jackson, 2008; Fiss \& Zajac, 2004; Mäkinen \& Kourula, 2012). However, as Mäkinen and Kourula (2012: 670) note, insights from institutional economics about national business systems have not yet been extended to normative theories of business ethics and corporate social responsibility. In this section, we articulate how the institutional economics perspective can help us understand when EAW is justified.

Prior business ethics literature on EAW, whether supportive or critical, generally proceeds as though it is attempting to specify a "best practice" for employment law

if it's not a requirement of justice to combat such treatment. Second, the critical point for our purposes is that even if one adopts the thicker conception of justice that critics of EAW adopt, this does not alone entail conclusions about the (non-) justifiability of EAW. We are grateful to an anonymous reviewer for raising this concern.

${ }^{10}$ Some might object that our proposed policy interventions are unlikely to be enacted. While of course, whether any of these proposals is in fact enacted is an empirical matter, we do not regard our proposals as an exercise in utopian ideal theorizing. Crucially, we regard our proposed interventions as no less politically feasible than proposals to supplant EAW in the United States with a just-cause regime.

${ }^{11}$ One might object that our policy proposals amount to only nominally preserving EAW and that these policy interventions amount to a de facto elimination of EAW. This is not quite right. Our proposed policy interventions aim to curb or eliminate the negative moral risks and bad side effects associated with EAW regimes, but in a way that preserves, and complements, the various positive aspects of EAW. In other words, these policy proposals serve as a hedge against the moral downsides of EAW, while preserving the benefits associated with EAW regimes: there are ways to throw the bathwater out but to keep the baby. We are grateful to an anonymous reviewer for urging us to discuss this point. 
that is applicable to all jurisdictions. One insight of institutional economics is the importance of context: rather than endorsing a single "best practice" for how a set of institutions should be configured, it recognizes that the functioning of a given institution depends on circumstance, including the broader institutional environment (Aguilera et al., 2008; Amable, 2016; Hall \& Soskice, 2001). Likewise, in our view, the justification for EAW is more contextual than previous analyses have acknowledged. This is due in large part to the presence of complementarities between employment law and other institutions that make up a jurisdiction's political economy.

Complementarities are present when there are reinforcing linkages between practices or institutions. When two practices or institutions, $x$ and $y$, complement each other, maintaining or implementing $x$ creates more value if $y$ is present than if it is not, and vice versa. For an example of a complementarity that could occur at the firm level, consider how the value of having flexible manufacturing equipment increases the value of the strategic decision to produce small batch sizes; likewise, producing small batch sizes increases the value of the strategic decision to have flexible manufacturing equipment (Milgrom \& Roberts, 1990; see also Porter, 1996).

Institutions of a jurisdiction's political economy can also exhibit complementarity. Considering the complementarities of the institutions that constitute a country's political economy - for example, corporate governance and financing systems, education and worker training systems, labor market policies, industrial relations systems, and contract and property law systems-is crucial when evaluating the justifiability of EAW. The reason for this is that EAW (or its alternative, a for-cause employment rule) is itself an important choice in the overall set of a country's institutions of political economy and plausibly interacts in important ways with other features of those institutions.

Perhaps the most developed theoretical framework characterizing different economic systems based on their main institutional complementarities comes from the "varieties of capitalism" literature (Hall \& Soskice, 2001). Varieties of capitalism distinguishes between two "ideal types" of capitalist systems that are built around different sets of complementary economic policy choices: liberal market economies (LMEs) and coordinated market economies (CMEs).

In this article, we employ the varieties of capitalism framework to illustrate our institutional complementarities approach to EAW. However, our approach is not linked in any fundamental way to varieties of capitalism specifically. ${ }^{12}$ Our main

\footnotetext{
${ }^{12}$ Other comparative institutional theories provide different accounts, though with some similarities to the varieties of capitalism approach. For example, Aoki (1994, 2001) argues that Japan's comparative advantage in incremental innovation and flat organizations and the United States' comparative advantage in radical innovation and networked forms of organization are due to distinctive institutional complementarities (see also Jackson \& Deeg, 2008). Another influential characterization of complementarities comes from Amable (2003), who distinguishes the neoliberal model of capitalism from the social democratic model of capitalism. The neoliberal model relies on complementarities between flexible employment policies and regulations that permit financial markets to react quickly to economic changes. The social democratic model relies on complementarities between employment protections that induce employees to invest in firm- and industry-specific skills and a centralized financial system.
} 
claim is that, when evaluating whether a jurisdiction should adopt EAW, we must attend to the ways in which EAW may complement (or not) other institutions of the jurisdiction's political economy. The varieties of capitalism literature provides one account of how these complementarities may work. What matters for our analysis are 1) whether the flexible labor market institutions of which EAW is a part are indeed complementary to other institutions in approximately the way varieties of capitalism proposes and 2) whether EAW specifically is necessary for unlocking the benefits of flexible labor market institutions. We provisionally rely on varieties of capitalism to provide support for these two claims.

According to varieties of capitalism, the different central complementary policy choices of LMEs versus CMEs support the development of different kinds of workforces, which in turn support different national comparative advantages. As transaction cost economics teaches us, investments in specific assets-assets whose value is specific to a certain employment, such as workers' industry and firmspecific skills - even when potentially mutually beneficial to participants in a transaction, can be difficult to facilitate when some actors are prone to behaving opportunistically (Williamson, 1985). CMEs feature strong employment protections, such as employment law that contains a for-cause requirement for dismissal. These employment protections allow CMEs to overcome market failures that cause workers to invest in suboptimal levels of firm- and industry-specific skills. LMEs, on the other hand, feature flexible labor market institutions, such as EAW, and produce a workforce with lower levels of firm- and industry-specific skills compared to CMEs.

As a result, CMEs versus LMEs tend to produce firms that excel at different kinds of innovation: incremental and radical innovation, respectively. Incremental innovations involve minor adjustments to processes that rely on existing technologies, whereas radical innovations involve fundamental, revolutionary technological changes (Dewar \& Dutton, 1986). This emphasis on firm- and industry-specific, rather than general, skills in their worker training and education systems gives CME firms an advantage compared to LME firms in "sectors characterized by incremental innovation and large firm-specific human capital investments" (Vitols, 2001: 359).

LMEs, on the other hand, have institutions that allow firms to pursue strategies around radical innovation. In LMEs, financial systems allow investors to quickly redeploy capital from profitable to unprofitable firms, markets rather than collective bargaining tend to mediate employment relations, top firm management has the power to implement new business strategies and restructure firms, and market mechanisms allow firms to acquire new technology quickly (Hall \& Soskice, 2001). Compared to CMEs, LMEs rely much more on markets, rather than coordination, to facilitate interaction between firms and their stakeholders. This makes LME labor significantly more mobile than CME labor-LME institutions encourage job hopping, whereas CME institutions promote longer tenures at one firm—and, as mentioned earlier, LME labor law has relatively few restrictions on layoffs. Thus an LME firm that wishes to develop a new product line can hire workers with the relevant knowledge and skills, knowing that, unlike a CME firm, it will be able to lay them off if the new product line does not end up being profitable (Hall \& Soskice, 2001: 40). 
We can understand LMEs and CMEs to represent two different policy equilibria. These emerge from competitive market processes that select for firms whose strategies align with their countries' economic-institutional environments and against those whose strategies are in disharmony with their countries' economic-institutional environments. This, according to varieties of capitalism, explains "why firms engaged in activities that entail high risks, intense competition, and high rates of labor turnover cluster in Silicon Valley, while firms engaged in very different activities that entail lower risks, close inter-firm collaboration, and low rates of labor turnover locate in Baden-Württemberg" (Hall \& Soskice, 2001: 37).

In other words, varieties of capitalism understands LMEs and CMEs as ideal types (Hall \& Soskice, 2001). Thus it does not claim that the countries it categorizes as LMEs or as CMEs contain all of the policies and institutions it identifies as characteristic of LMEs or CMEs. However, bearing in mind this caveat, varieties of capitalism identifies the United States, the United Kingdom, New Zealand, Ireland, Canada, and Australia as LMEs and Austria, Belgium, Denmark, Finland, Iceland, Germany, Japan, the Netherlands, Norway, Sweden, Switzerland, and South Korea as CMEs (Hall \& Gingerich, 2009).

If varieties of capitalism is broadly accurate as a comparative theory of national economic institutions, then we would suggest that the countries whose approaches identify as LMEs have reason to adopt or maintain an EAW employment rule. ${ }^{13}$ We would also suggest that the CME countries of Continental Europe, plus Iceland, Japan, and South Korea, have strong reasons against adopting EAW. Whether a jurisdiction should adopt EAW depends crucially on how EAW is likely to interact with other policies in the jurisdiction's existing institutional arrangement.

This is to say, if various countries' economies have national comparative advantages that depend on mutually reinforcing institutional complementarities, then decisions about particular policies, such as EAW, should not be isolated from decisions about other, complementary policies. If flexible labor market policies are part of a larger set of complementary policy choices, then we should be especially worried that eliminating EAW may have negative, unintended consequences for the broader economy. The converse, of course, may also apply for CME economies: replacing for-cause employment with EAW could interact negatively with the broader overall set of CME economic policies that give CMEs a comparative advantage in industries that rely heavily on incremental innovation. Therefore, in our view, there is strong reason to believe that the United States and Germany, for example, are both making justifiable policy choices when they elect to retain EAW and for-cause dismissal, respectively.

For example, a powerful justification for retaining EAW in the United States, and relying on other policy changes to address EAW critics' concerns, is that the US economy has developed comparative advantages in certain industries-the

\footnotetext{
${ }^{13}$ Of the countries varieties of capitalism identifies as LMEs, the United States is the only one that is an EAW jurisdiction (see Harcourt, Hannay, \& Lam, 2013).
} 
technology sector is an obvious example - that depend on disruptive innovation, in part because of a complex set of complementary institutional choices, including EAW. For example, making it relatively easy for firms to hire, fire, and lay off workers reduces the high degree of risk associated with investing in disruptive innovation, improves firms' abilities to adjust to economic disruptions, and allows LME firm managers to implement changes in firms relatively quickly (Hall \& Soskice, 2001). It also complements LME education systems' emphasis on general, rather than firm- or industry-specific, skills, as well as LME firms' reliance on labor mobility as a form of technology transfer, rather than the cooperative, intercorporate linkages on which CME firms rely (Hall \& Soskice, 2001). Eliminating EAW could erode the foundations of some of the main national competitive advantages that produce the disruptive innovations that drive the economy of the United States and often have positive spillover effects for the rest of the world as well. ${ }^{14}$ Thus there is a strong case that the United States should retain EAW and rely on some of the alternative means we listed earlier to address EAW critics' concerns. ${ }^{15}$

Our argument would also imply that non-US LME countries, none of which are currently EAW regimes, have reason to adopt EAW. Some may find this implausible. After all, LME regimes without EAW appear to have systems of political economy that operate successfully and generate economic growth and prosperity. Do they really have good reason to adopt EAW?

The arguments we have made in this section suggest that they do, especially if they adopt the policy reforms we list in section 3. However, we also recognize the need for additional empirical research regarding EAW's importance in LME economy contexts, especially to justify non-US LME countries moving in the direction of EAW. ${ }^{16}$ Finally, we note that a strong rebuttal of our argument would require

\footnotetext{
${ }^{14}$ Some US-focused legal scholars have proposed tweaks to employment law that would curtail EAW in some limited ways to protect employees from unjust dismissals, for example, by modifying EAW to include a "personal autonomy presumption" (Bodie, 2017) or by expanding the tort of wrongful discharge (Corbett, 2018). Perhaps advocates of these approaches would argue that they are fine-tuned enough to limit the aspects of EAW that expose employees to arbitrary treatment while retaining the aspects of EAW that allow them to escape it. The worry about these suggestions is that they may have the unintended negative consequence of increasing firms' hiring costs, making firms more reluctant to hire, thereby limiting the available exit options for workers in situations in which they are vulnerable to arbitrary treatment.

${ }^{15}$ A further point in favor of an economy like the United States' maintaining EAW appeals to the vulnerabilities that a for-cause dismissal regime may create compared to an EAW regime. Comparative institutional analysis requires us to consider not just the vulnerabilities of employees under EAW but also the vulnerabilities associated with for-cause dismissal. There is some evidence that US states that have adopted greater protections for employees against termination, such as prohibitions on unjust dismissal, increase firms' reliance on outsourced, temporary labor at the expense of direct, full-time employment (Autor, 2003). Furthermore, although jurisdictions with stronger employment protections do not necessarily have a higher unemployment rate than jurisdictions with weaker employment protections, jurisdictions with strong employment protection do tend to have much greater durations of unemployment (Blanchard \& Portugal, 2001). It is reasonable to worry about the plight of the long-term unemployed in jurisdictions with the kinds of labor market restrictions characteristic of CMEs.

${ }^{16}$ We have not claimed that EAW is, strictly speaking, a necessary (or sufficient) condition for the effective functioning of LME economies. Rather, our view is that EAW supports the economic performance of LMEs: all
} 
evidence that, contrary to the theoretical arguments we lay out herein, EAW is not an important component of LMEs' flexible labor market institutions.

To summarize, on our institutional complementarities account, whether a country should adopt EAW versus a for-cause termination rule depends not only on immediate ethical considerations, such as freedom, autonomy, and preventing domination, but also on broader factors of a country's political economy that interact with its regulatory framework for labor and contracts. If a policy complements other institutional features in a way that is overall likely to be beneficial for society, then we should be hesitant to alter one of those features, especially if the problems that motivate us to do so can be addressed in other ways that avoid potentially undermining some of the interdependent mechanisms by which a society's institutions facilitate economic benefits that accrue to its citizens. ${ }^{17}$ Because of these considerations, although we grant that EAW legally allows employers to treat employees unethically in ways for-cause dismissal forbids, there nevertheless is strong reason to preserve EAW in certain jurisdictions, including the United States.

\section{THE ETHICS OF HIRING AND FIRING}

Under an EAW regime of employment law, employees are in an important sense in a more precarious position than employees in places with for-cause employment. As the EAW critics argue, this can undermine employee freedom (Anderson, 2015, 2017) and make employees vulnerable to unethical treatment at the hands of their employers (McCall, 2003; Werhane et al., 2004). In addition to the policy interventions we suggested in section 3, we affirm that employers in EAW jurisdictions should be held to certain ethical obligations not to exploit their employees' precarity. (We thus agree with Werhane and Radin [1999: 259] that EAW should not be treated as a "guiding principle" of the ethics of hiring and firing.)

Here is one (not the only) way to justify such obligations. In line with many critics of EAW, as autonomous moral persons, employees have a right not to be exploited or treated arbitrarily. This right imposes a corresponding duty on someone to take measures to protect employees from domination and arbitrary treatment. Critically, on our view, whom it imposes a duty on — whether employers, the government, elected representatives, or the electorate that empowers them-can vary. In countries with for-cause dismissal, the burden that various actors-including employers-must bear to ensure that this right is respected is reduced because for-cause dismissal eliminates some of the means by which employers can dominate and mistreat employees. In countries with EAW, however, this duty might fall on policy makers to institute

\footnotetext{
else being equal, in the LME context, EAW leads to better economic performance than for-cause dismissal. But again, more empirical work is needed to tease out the precise nature and magnitude of these relationships.

${ }^{17}$ To be clear, this does not commit us to the view that just any complementary set of institutions can be justified because of the presence of complementarities. Inherently unjust institutional arrangements (e.g., involving forced or child labor) can exhibit complementarity but should nevertheless be opposed and resisted. Complementarity considerations become relevant only when a set of institutions has been shown not to be inherently unjust.
} 
policies (of the sort we discussed in section 3) that could protect employees from unjust domination or arbitrary treatment.

But this does not crowd out the importance of managers themselves exercising their own moral autonomy in EAW regimes (as well as the development and support of cultures and informal norms that discourage and disincentivize abuse, domination, and arbitrary treatment of employees). Radin and Werhane (2003: 120) write that, as an ethical matter, firms owe their employees "at a minimum... due process for all employment changes, employability training, protection of fundamental rights such as free speech and privacy, and the provision of adequate information to employees about their future and the future of the company." We agree that employers ought to ensure the provision of many of these morally significant goods. These ethical requirements that Radin and Werhane articulate are not merely consistent with supporting EAW; in an important sense, they derive their practical significance from EAW. The very need for identifying ethical requirements arises largely in EAW regimes because for-cause regimes lack the opportunity for managers to exercise their moral autonomy with respect to such ethical requirements. Thus the ethical requirements Radin and Werhane highlight pair well with the choice of EAW as a policy, because they provide one potentially promising remedy to some of the abuse and mistreatment of employees that EAW, in the wrong circumstances, can allow. ${ }^{18}$

A notable circumstance in which firms in EAW jurisdictions incur greater ethical obligations with respect to their employees than firms in for-cause dismissal jurisdictions is when firms induce employees to develop firm-specific skills. One of the economic advantages of a for-cause dismissal policy is that it facilitates development of firm-specific skills (Hall \& Soskice, 2001). But firms in EAW regimes also depend on their employees developing firm-specific skills to some extent. EAW firms therefore must overcome the assurance problem that for-cause dismissal helps solve to induce employees to invest in firm-specific, rather than general, skills.

One mechanism for overcoming this problem, of course, is contract: EAW is a default rule, but employers and employees can agree to contractual assurances that protect employees who develop firm-specific skills from potential opportunistic behavior by their employers (de los Reyes \& Martin, 2019; Williamson, 1985). Contract can also protect employers from opportunism on the part of employees, for example, through noncompete clauses (see Frye, 2020). However, sometimes contractual solutions to these kinds of assurance problems are not feasible: for example, an employer may lack the resources to make a longer-term contractual commitment

\footnotetext{
${ }^{18}$ We do not here offer an argument for the various employment ethics obligations of the sort Radin and Werhane discuss. Rather, our purpose is to show that even if we presume that the various moral concerns critics of EAW have raised over the years are legitimate ones, it may nevertheless be the case that EAW is justified in certain jurisdictions. To be clear, we do not deny that the critics of EAW are likely motivated by concern for how workers are in fact treated in jurisdictions where EAW is the legal presumption. Furthermore, we assume that EAW critics are exactly correct in their characterizations of the various ways in which employees are mistreated. What we are calling into question, however, is what normatively follows from this mistreatment. We thank an anonymous reviewer for pressing us to clarify this point.
} 
to an employee. Also, employers and employees lack the knowledge necessary to devise contractual solutions to all potential contingencies.

For this reason, in EAW regimes, inducing employees to develop firm-specific skills will typically require some level of informal trust that the employer will not take advantage of the reduced bargaining power of an employee who agrees to invest in firm-specific skills rather than general skills. These kinds of informal trust-based relationships require firms to embrace deeper ethical commitments to their employees than the minimal legal mandate of the EAW default rules. Therefore firms in EAW regimes that rely on employees investing in firm-specific skills incur greater ethical obligations not to take advantage of the vulnerability this can create for their employees, in contrast to EAW firms that do not significantly rely on firmspecific skills or to firms in for-cause dismissal jurisdictions.

Thus, in our view, there is a strong case for decoupling support for EAW's relatively minimal formal legal regulatory requirements on the employment relationship from support for the view that there are only minimal ethical requirements governing how employers are permitted to treat their employees in the employment relationship. ${ }^{19}$ Indeed, the ethical obligations constraining employer action are plausibly more stringent in EAW regimes than in for-cause regimes: even though the moral rights of employees do not depend on institutional context, the duties that these rights imply for employers do depend on institutional context, because they depend on how much responsibility other actors take for ensuring that employee rights are respected.

\section{CONCLUSION: TOWARD A THEORY OF EMPLOYMENT ETHICS}

The focus of this article has been EAW: whether it can be justified and what the ethical implications are for firms operating in EAW jurisdictions. We have proposed an approach to thinking about EAW that is sensitive to the main institutional complementarities between a jurisdiction's employment law and the other institutions and policies that constitute its political economy. Thus, in our view, the case for EAW is much more context dependent than previous analyses have recognized.

We would like now to offer some suggestions about a broader project that we have not undertaken in this article: generating a comprehensive theory of employment ethics. On the basis of some ethical judgments that we take to be fairly intuitive, but cannot defend at great length here, we would like to indicate some desiderata for an acceptable theory of employment ethics.

First, in public political discourse, it is common to speak of firings and layoffs as bad or unethical because they are harmful to the employee who loses his or her job. But this is clearly overly simplistic. A modern economy simply cannot function

\footnotetext{
${ }^{19}$ Is something lost by employers not having the prerogative to engage in the legally permissible but morally dubious practices that EAW regimes allow? The arguments in this article have supported two main claims in response to this challenge. First, EAW can contribute to reducing employee vulnerability to domination, subordination, and arbitrary treatment on the part of employers by supporting employees' right to exit abusive employment situations. Second, as a policy that contributes to labor market flexibility, EAW may contribute to the economic benefits that are associated with flexible labor markets.
} 
without firing and layoffs. For example, it clearly must be permissible for a firm to lay off a worker whose skills are no longer valuable to the firm due to economic disruption. An acceptable theory of employment ethics thus must recognize that a range of firings and layoffs are morally permitted, at least when carried out in an appropriate and professional way (see Kim, 2014).

Second, many purported rights of employees place corresponding duties on other parties to ensure that those rights are respected-for example, the right to a living wage, the right to employee benefits like health care, and the right to continuing employment. In our view, business ethicists are sometimes too quick to identify firms as the only or main party who bear the duties associated with these employee rights (Brennan, 2019). An adequate account of employment ethics must be able to explain why burdens associated with respecting employee rights must be borne by the employer, rather than the state or society more broadly.

Third, and relatedly, as our arguments about EAW and for-cause employment regimes have illustrated, an adequate account of employment ethics must be sensitive to institutional context, for example, whether extensive social insurance and social welfare programs are available in a particular society is likely to affect the duties of employers toward their employees. Even if the moral rights of employees are the same across institutional contexts, the duties that these rights imply for employers will likely depend on how much responsibility the state or other social institutions in a particular society take for upholding employee rights.

Fourth, most work on employment ethics focuses on the rights of employees. This makes sense to a degree: rights of employees, and their violation, represent pressing moral problems in modern, corporate, market-oriented economic systems. However, the employment relationship involves employers in addition to employees, and an adequate account of employment ethics must specify the moral rights of employers, not just of employees. It must also explain the implications of particular employer rights for the ethical duties of employees.

Fifth, and finally, an adequate account of employment ethics must be able to explain the moral difference between the employment relationship and other kinds of commercial relationships, including especially more arm's-length relationships of market exchange and market contracting. When, and for what reason, does a firm owe greater moral consideration to its employees than it does to people with whom it transacts who are not employees? A full theory of employment ethics should be able to answer this question.

On the basis of the analysis we have conducted in this article, we offer a suggestion for researchers attempting to develop a broader theory of employment ethics. We believe that the theories of institutional economics on which we have drawn here have the potential to break new ground in business ethics beyond the subject of EAW that has been our focus. One common, and essential, approach to building normative business ethics theory is to apply normative ethical theories, such as Kantian deontology, utilitarianism, virtue ethics, or Habermasian discourse ethics, to business ethics topics, such as corporate governance, corporate social responsibility, employer-employee relations, and marketing. An institutional economics approach to business ethics, by contrast, seeks insight on ethical issues in business by trying to 
gain a better understanding of what makes the institutions within which business takes place function well.

Business ethics scholars have built normative research on the insights of some prominent institutional economics scholars, especially Ronald Coase and Oliver Williamson (e.g., Freeman, Harrison, Wicks, Parmar, \& De Colle, 2010; Heath, 2014; Singer, 2018). But other important strands of literature from scholars in institutional economics have to this point been largely unexplored in normative business ethics scholarship, for example, insights about how human societies have dealt with environmental and social problems arising from challenges governing common-pool resources (e.g., Ostrom, 1990) and about how human societies have overcome violence and poverty to achieve (relative) peace and prosperity (e.g., Acemoglu \& Robinson, 2013; North, Wallis, \& Weingast, 2009). These seminal works, and the literatures they have generated, have implications for how we should understand and think about issues of ethics and justice in business beyond the specific issue of EAW that has been our focus here, including for employment ethics more broadly.

To conclude, defenders of EAW have argued that it promotes autonomy and efficiency, whereas critics have argued that it allows for the subordination, domination, and arbitrary treatment of employees. We intervene in the debate surrounding EAW by arguing that blanket prescriptions for or against EAW are unjustified. In particular, we argue that the justifiability of EAW depends on institutional arrangements: jurisdictions with institutional complementarities that depend on flexible labor markets are justified in adopting or retaining EAW, whereas jurisdictions with institutional complementarities that depend on secure employment arrangements to induce workers to invest in developing industry- and firm-specific skills are justified in adopting or retaining for-cause dismissal rules in their employment law. Notably, our view also takes seriously the moral concerns raised by critics of EAW by showing how these concerns can be mitigated through public policy measures that do not require eliminating EAW.

\section{Acknowledgments}

For helpful comments and feedback, we thank Suneal Bedi, Brian Berkey, Matthew Caulfield, Thomas Donaldson, Nicholas Geiser, Bill Glod, Alexander Guerrero, Michael Kates, Jooho Lee, Tammy Madsen, J. P. Messina, Alan Strudler, Kok-Chor Tan, Bas van der Vossen, and the audience at the 2020 Society for Business Ethics annual meeting. We also thank the anonymous referees of this journal and former editor in chief Bruce Barry for their helpful feedback.

\section{REFERENCES}

Abrams, R. I., \& Nolan, D. R. 1985. Toward a theory of "just cause" in employee discipline cases. Duke Law Journal, 34(2): 594-623.

Acemoglu, D., \& Robinson, J. A. 2013. Why nations fail: The origins of power, prosperity, and poverty. New York: Crown. 
Aguilera, R. V., Filatotchev, I., Gospel, H., \& Jackson, G. 2008. An organizational approach to comparative corporate governance: Costs, contingencies, and complementarities. Organization Science, 19(3): 475-92.

Alchian, A. A., \& Demsetz, H. 1972. Production, information costs, and economic organization. American Economic Review, 62(5): 777-95.

Amable, B. 2003. The diversity of modern capitalism. New York: Oxford University Press.

Amable, B. 2016. Institutional complementarities in the dynamic comparative analysis of capitalism. Journal of Institutional Economics, 12(1): 79-103.

Anderson, E. 2015. Liberty, equality, and private government (Tanner Lectures in Human Values). Salt Lake City: Tanner Humanities Center, University of Utah.

Anderson, E. 2017. Private government: How employers rule our lives (and why we don't talk about it). Princeton, NJ: Princeton University Press.

Aoki, M. 1994. The contingent governance of teams: Analysis of institutional complementarity. International Economic Review, 35(3): 657-76.

Aoki, M. 2001. Toward a comparative institutional analysis. Cambridge, MA: MIT Press.

Arnold, D. G. 2009. Working conditions: Safety and sweatshops. In G. G. Brenkert \& T. L. Beauchamp (Eds.), The Oxford handbook of business ethics: 628-54. New York: Oxford University Press.

Autor, D. H. 2003. Outsourcing at will: The contribution of unjust dismissal doctrine to the growth of employment outsourcing. Journal of Labor Economics, 21(1): 1-42.

Baker, D. 2015. Job lock and employer-provided health insurance: Evidence from the literature (AARP Public Policy Institute Research Report). https://www.aarp.org/ ppi/info-2015/job-lock-and-employer-provided-healthcare.html.

Barry, B. 2007a. The cringing and the craven: Freedom of expression in, around, and beyond the workplace. Business Ethics Quarterly, 17(2): 263-96.

Barry, B. 2007b. Speechless: The erosion of free expression in the American workplace. San Francisco: Berrett-Koehler.

Bennett, M., Polden, D., \& Ruben, H. 1998. Employment relationships: Law and practice. New York: Aspen Law and Business.

Bhargava, V. R. 2020. Firm responses to mass outrage: Technology, blame, and employment. Journal of Business Ethics, 163(3): 379-400.

Blanchard, O., \& Portugal, P. 2001. What hides behind an unemployment rate: Comparing Portuguese and U.S. labor markets. American Economic Review, 91(1): 187-207.

Bodie, M. T. 2017. The best way out is always through: Changing the employment at-will default rule to protect personal autonomy. University of Illinois Law Review, 2017 (1): 223-69.

Bowles, S., \& Gintis, H. 1992. Power and wealth in a competitive capitalist economy. Philosophy and Public Affairs, 21(4): 324-53.

Brennan, J. 2019. Should employers pay a living wage? Journal of Business Ethics, 157(1): $15-26$.

Campbell, J. L. 2007. Why would corporations behave in socially responsible ways? An institutional theory of corporate social responsibility. Academy of Management Review, 32(3), 946-67.

Corbett, W. R. 2018. Finding a better way around employment at will: Protecting employees' autonomy interests through tort law. Buffalo Law Review, 66(5): 1071-90.

Daugherty, C. R. 1966. Enterprise wire company and enterprise independent union, vol. 46: 359. Labor Arbitration Report. 
De los Reyes, G., Jr., \& Martin, K. 2019. Not from guile but from entitlement: Lawful opportunism capitalizes on the cracks in contracts. Buffalo Law Review, 67(1): 1-52.

Dewar, R. D., \& Dutton, J. E. 1986. The adoption of radical and incremental innovations: An empirical analysis. Management Science, 32(11): 1422-33.

Epstein, R. A. 1984. In defense of the contract at will. University of Chicago Law Review, 51(4): 947-82.

Estlund, C. 1995. Free speech and due process in the workplace. Indiana Law Journal, 71(1): 101-52.

Estlund, C. 2007. Free speech rights that work at work: From the First Amendment to due process. UCLA Law Review, 54(6): 1463-96.

Estlund, C. 2018. Book review: Rethinking autocracy at work: Review of Private government: How employers rule our lives (and why we don't talk about it), by Elizabeth Anderson. Harvard Law Review, 131(3): 795-826.

Fiss, P. C., \& Zajac, E. J. 2004. The diffusion of ideas over contested terrain: The (non) adoption of a shareholder value orientation among German firms. Administrative Science Quarterly, 49(4): 501-34.

Freeman, R. E., Harrison, J. S., Wicks, A. C., Parmar, B. L., \& De Colle, S. 2010. Stakeholder theory: The state of the art. Cambridge: Cambridge University Press.

Frye, H. 2020. The ethics of noncompete clauses. Business Ethics Quarterly, 30(2), 229-49.

Goodin, R. E. 1986. Protecting the vulnerable: A re-analysis of our social responsibilities. Chicago: University of Chicago Press.

Hall, P. A., \& Gingerich, D. W. 2009. Varieties of capitalism and institutional complementarities in the political economy: An empirical analysis. British Journal of Political Science, 39(3): 449-82.

Hall, P. A., \& Soskice, D. 2001. An introduction to varieties of capitalism. In P. A. Hall \& D. Soskice (Eds.), Varieties of capitalism: The institutional foundations of comparative advantage: 1-68. New York: Oxford University Press.

Harcourt, M., Hannay, M., \& Lam, H. 2013. Distributive justice, employment-at-will and just-cause dismissal. Journal of Business Ethics, 115(2): 311-25.

Heath, J. 2014. Morality, competition, and the firm: The market failures approach to business ethics. New York: Oxford University Press.

Hirschman, A. O. 1970. Exit, voice, and loyalty: Responses to decline in firms, organizations, and states. Cambridge, MA: Harvard University Press.

Hsieh, N. 2005. Rawlsian justice and workplace republicanism. Social Theory and Practice, 31(1): 115-42.

Ioannou, I., \& Serafeim, G. 2012. What drives corporate social performance? The role of nation-level institutions. Journal of International Business Studies, 43(9): 834-64.

Jackson, G., \& Deeg, R. 2008. Comparing capitalisms: Understanding institutional diversity and its implications for international business. Journal of International Business Studies, 39(4): 540-61.

Katz, L. F., \& Krueger, A. B. 1999. The high-pressure US labor market of the 1990s. Brookings Papers on Economic Activity, 1: 1-87.

Kenworthy, L. 2002. Corporatism and unemployment in the 1980s and 1990s. American Sociological Review, 67(3): 367-88.

Kim, T. W. 2014. Decent termination: A moral case for severance pay. Business Ethics Quarterly, 24(2), 203-27.

Koven, A. M., \& Smith, S. L. 2006. Just cause: The seven tests (3rd ed., K. May, Ed.). Washington, DC: Bureau of National Affairs. 
Madrian, B. C. 1994. Employment-based health insurance and job mobility: Is there evidence of job-lock? Quarterly Journal of Economics, 109(1): 27-54.

Maitland, I. 1989. Rights in the workplace: A Nozickian argument. Journal of Business Ethics, 8(12): 951-54.

Mäkinen, J., \& Kourula, A. 2012. Pluralism in political corporate social responsibility. Business Ethics Quarterly, 22(4): 649-78.

Marx, K. 2019. Capital: Volume 1 (E. Aveling \& S. Moore, Trans.). Mineola, NY: Dover.

Matten, D., \& Moon, J. 2008. "Implicit" and "explicit" CSR: A conceptual framework for a comparative understanding of corporate social responsibility. Academy of Management Review, 33(2): 404-24.

McCall, J. J. 2003. A defense of just cause dismissal rules. Business Ethics Quarterly, 13(2): $151-75$.

McCall, J. J., \& Werhane, P. H. 2009. Employment at will and employee rights. In G. G. Brenkert \& T. L. Beauchamp (Eds.), The Oxford handbook of business ethics: 602-27. New York: Oxford University Press.

Milgrom, P., \& Roberts, J. 1990. The economics of modern manufacturing: Technology, strategy, and organization. American Economic Review, 80(3): 511-28.

Muhl, C. J. 2001. The employment-at-will doctrine: Three major exceptions. Monthly Labor Review, 124: 3-11.

North, D. C., Wallis, J. J., \& Weingast, B. R. 2009. Violence and social orders: A conceptual framework for interpreting recorded human history. Cambridge: Cambridge University Press.

Ostrom, E. 1990. Governing the commons: The evolution of institutions for collective action. New York: Cambridge University Press.

Ozimek, A., \& Ferlez, M. 2018. The Fed's mistake. Moody's Analytics.

Peng, M. W., Sun, S. L., Pinkham, B., \& Chen, H. 2009. The institution-based view as a third leg for a strategy tripod. Academy of Management Perspectives, 23(3): 63-81.

Pettit, P. 1997. Republicanism: A theory of freedom and government. New York: Oxford University Press.

Porter, M. E. 1996. What is strategy? Harvard Business Review, 74(6): 61-78.

Radin, T. J., \& Werhane, P. H. 1996. The public/private distinction and the political status of employment. American Business Law Journal, 34(2): 245-60.

Radin, T. J., \& Werhane, P. H. 2003. Employment-at-will, employee rights, and future directions for employment. Business Ethics Quarterly, 13(2): 113-30.

Reeves, T. Z. 2016. Are the seven tests of just cause still relevant? https://cdn.website-editor. net/9e71c80613bb4a7f958014acace5149e/files/uploaded/Article5JustCause\% 2520TZaneReeves.pdf.

Singer, A. A. 2018. The form of the firm: A normative political theory of the corporation. New York: Oxford University Press.

Skedinger, P. 2011. Employment consequences of employment protection legislation. Nordic Economic Policy Review, 1: 45-83.

Snyder, J. 2010. Exploitation and sweatshop labor: Perspectives and issues. Business Ethics Quarterly, 20(2): 187-213.

Stroupe, K. T., Kinney, E. D., \& Kniesner, T. J. J. 2001. Chronic illness and health insurancerelated job lock. Journal of Policy Analysis and Management, 20(3): 525-44.

Sugarman, S. D. 2003. "Lifestyle" discrimination in employment. Berkeley Journal of Employment and Labor Law, 24(2): 377-438.

Taylor, R. S. 2017. Exit left: Markets and mobility in republican thought. Oxford: Oxford University Press. 
Vitols, S. 2001. Varieties of corporate governance: Comparing Germany and the UK. In P. A. Hall \& D. Soskice (Eds.), Varieties of capitalism: The institutional foundations of comparative advantage: 337-60. Oxford: Oxford University Press.

Werhane, P. H. 1999. Justice and trust. Journal of Business Ethics, 21: 237-49.

Werhane, P., \& Radin, T. J. 1999. Employment at will and due process. In T. L. Beauchamp $\&$ N. E. Bowie (Eds.), Ethical issues in business: A philosophical approach (6th ed.): 266-75. Upper Saddle River, NJ: Prentice Hall.

Werhane, P., Radin, T. J., \& Bowie, N. E. 2004. Employment and employee rights. Malden, MA: Blackwell.

Williamson, O. E. 1985. The economic institutions of capitalism: Firms, markets, and relational contracting. New York: Free Press.

Zwolinski, M. 2007. Sweatshops, choice, and exploitation. Business Ethics Quarterly, 17(4): 689-727.

VIKRAM R. BHARGAVA (vrb@gwu.edu, corresponding author) is an assistant professor of strategic management and public policy at the George Washington University School of Business. He received a joint $\mathrm{PhD}$ from the University of Pennsylvania in ethics and legal studies (Wharton) and philosophy (School of Arts and Sciences).

CARSON Young is an assistant professor of management in the School of Business and Management at SUNY Brockport. He received his PhD in 2019 from the University of Pennsylvania's Wharton School in ethics and legal studies.

This is an Open Access article, distributed under the terms of the Creative Commons Attribution licence (https://creativecommons.org/licenses/by/4.0/), which permits unrestricted re-use, distribution, and reproduction in any medium, provided the original work is properly cited. 